\title{
Strategi Komunikasi Yang Mendukung Perkembangan Pariwisata Berbasis Ekonomi Kerakyatan
}

\author{
Retno Manuhoro Setyowati \\ (manuhoro2002@yahoo.com)
}

(Staf Pengajar Jurusan Ilmu Komunikasi Universitas Semarang)

\begin{abstract}
:
This research was emerged by Centra Java Government policy which placed tourism sector as the second key sectors beside agriculture and industries. A kind of tourism force is by ecotourism wich environmentally responsible travel and visits to relatively undisturbed natural areas, in order to enjoy and appreciate nature and any accompanying cultural features, both past and present, that promote conservation, has low visitor impact, and provides for beneficially active socio-economic involvement of local population. Then, the strategic communication choose Participatory Rural Appraisal (PRA) to increase them. PRA is a participatory approach, new innovation method for improving efficacy and rapidity in data collection. Participatory method was interested the community in prepare the action program and developing the learning process forsolving the environment problems. Leading by Pamong Budaya as opinion leader, this strategic communication is a way tocreate an effective communication and automatically help rural community to increase their live by ecotourism.
\end{abstract}

Kata Kunci : Strategic communication, Community-based ecotourism, Opinion leader

\section{Pendahuluan}

Rencana strategis Jawa Tengah 2009-2013 mengambil kebijakan untuk pengembangan pariwisata berbasis ekonomi kerakyatan. Salah satu tujuan dari kebijakan ini adalah untuk meningkatkan taraf hidup masyarakat, terutama masyarakat yang tinggal di sekitar lokasi wisata. Pariwisata berbasis ekonomi kerakyatan ini selanjutnya disebut sebagai ekowisata oleh para pelaku dan pakar pariwisata. Pola ekowisata dinilai sebagai jalan untuk meminimalkan dampak yang negatif terhadap lingkungan dan budaya setempat serta mampu meningkatkan pendapatan ekonomi bagi masyarakat setempat juga nilai konservasi. Bahwa kemudian akhirnya tercipta sebuah ekowisata di beberapa tempat, ini tentunya menarik untuk dicermati. Hal ini bukan berarti menjadi sebuah gerakan yang selalu mendukung program pemerintah, namun lebih pada pengamatan pola dan strategi komunikasi yang dilakukan antar beberapa kepentingan, terutama komunikasi dalam mendorong kemajuan masyarakat yang terlibat di dalamnya. Pola ekowisata berbasis masyarakat adalah pola pengembangan ekowisata yang mendukung dan memungkinkan keterlibatan penuh oleh masyarakat setempat dalam perencanaan, pelaksanaan, dan pengelolaan usaha ekowisata dan segala keuntungan yang diperoleh (CeballosLuscurain, 1996). Ekowisata berbasis masyarakat merupakan usaha ekowisata yang menitikberatkan peran aktif 
komunitas. Hal tersebut didasarkan kepada kenyataan bahwa masyarakat memiliki pengetahuan tentang alam serta budaya yang menjadi potensi dan nilai jual sebagai daya tarik wisata, sehingga pelibatan masyarakat menjadi mutlak. Pola ekowisata berbasis masyarakat mengakui hak masyarakat lokal dalam mengelola kegiatan wisata di kawasan yang mereka miliki secara adat ataupun sebagai pengelola. Ekowisata berbasis masyarakat dapat menciptakan kesempatan kerja bagi masyarakat setempat, dan mengurangi kemiskinan, di mana penghasilan ekowisata adalah dari jasa-jasa wisata untuk turis: fee pemandu; ongkos transportasi; homestay; menjual kerajinan,dan lainlain. Pada akhirnya, ekowisata membawa dampak positif terhadap pelestarian lingkungan dan budaya asli setempat yang diharapkan akan mampu menumbuhkan jati diri dan rasa bangga antar penduduk setempat yang tumbuh akibat peningkatan kegiatan ekowisata. Tataran implementasi ekowisata perlu dipandang sebagai bagian dari perencanaan pembangunan terpadu yang dilakukan di suatu daerah. Untuk itu, pelibatan para pihak terkait mulai dari level komunitas, masyarakat, pemerintah, dunia usaha dan organisasi non pemerintah diharapkan membangun suatu jaringan dan menjalankan suatu kemitraan yang baik sesuai peran dan keahlian masing-masing.

\section{Pembahasan}

Beberapa aspek kunci dalam ekowisata berbasis masyarakat adalah:

1. Masyarakat membentuk panitia atau lembaga untuk pengelolaan kegiatan ekowisata di daerahnya, dengan dukungan dari pemerintah dan organisasi masyarakat (nilai partisipasi masyarakat dan edukasi)
2. Prinsip local ownership (pengelolaan dan kepemilikan oleh masyarakat setempat) diterapkan sedapat mungkin terhadap sarana dan pra-sarana ekowisata, kawasan ekowisata, dll (nilai partisipasi masyarakat)

3. Homestay menjadi pilihan utama untuk sarana akomodasi di lokasi wisata (nilai

ekonomi dan edukasi)

4. Pemandu adalah orang setempat (nilai partisipasi masyarakat)

5. Perintisan, pengelolaan dan pemeliharaan obyek wisata menjadi tanggungjawab masyarakat setempat, termasuk penentuan biaya (fee) untuk wisatawan (nilai ekonomi dan wisata).

Sekilas program pemerintah ini memang menarik dan bisa dianggap sebagai salah satu solusi dari peningkatan kesejahteraan rakyat. Meski demikian, mewujudkan hal ini agar menjadi sebuah bentuk kegiatan rakyat yang riil tentu saja memerlukan serangkaian usaha yang diikuti dengan berbagai usaha komunikasi antar berbagai kepentingan.

Menciptakan sebuah ekowisata baru memerlukan sebuah kunci pembuka, yaitu adanya komunikasi intensif sekaligus memikirkan strateginya. Alangkah beruntungnya jika komunikator berada pada struktur masyarakat yang kondusif, karena akan memudahkan langkah awal untuk sekedar membuka wacana dan percakapan mula-mula. Namun persoalannya menjadi lain ketika diperhadapkan pada kondisi sosial yang masih membutuhkan prolog dari sisi internal masyarakat.

Mengilas balik perjalanan air terjun atau Curug Tujuh Bidadari (C7B) yang resmi di launching beberapa bulan yang lalu, sekiranya dapat menjadi 
contoh yang menjelaskan uniknya membangun strategi komunikasi di desa yang menyandang predikat desa tertinggal. Desa Keseneng terletak di Kecamatan Sumowono, Kabupaten Semarang. Disebelah selatan, desa ini berbatasan dengan Kabupaten Temanggung, dan di sebelah utara berbatasan dengan kabupaten Kendal. Berdasarkan data Kecamatan Sumowono, hampir separuh penduduk desa ini masuk dalam daftar penerima Bantuan Tunai Langsung dan masuk dalam kategori penerima dana Inpres Desa Tertinggal. Kriteria desa tertinggal antara lain dilihat dari ketersediaan jalan utama desa, lapangan usaha bagi mayoritas penduduk, fasilitas pendidikan, fasilitas kesehatan, fasilitas komunikasi, kepadatan penduduk per $\mathrm{km} 2$, sumber air minum, sumber bahan bakar, persentase penggunaan listrik dan persentase pertanian, jumlah penduduk miskin dan sebagainya (BPS dan Depsos, 2002 : 4 ). Desa Keseneng memang tercatat sebagai desa tertinggal , namun di sisi lain kekayaan alamnya masih bisa digali sebagai obyek wisata yang potensial. Ini selanjutnya menjadi tantangan baik bagi pemerintah setempat maupun masyarakatnya sendiri. Tantangan dimulai dari membuka forum komunikasi serta menyiapkan serangkaian strategi yang bisa mendorong air terjun desa itu sebagai andalan warganya. Kerumitan kondisi struktur desa dan psikologi sosial yang terlanjur terpuruk menimbulkan tantangan baru bagi para pengemban tugas.

Dalam proses komunikasi, ada lima elemen dasar yang dikemukakan oleh Harold Lasswell dengan istilah "Who Says What in Which Channel to Whom with What Effect". Kelima elemen dasar tersebut adalah Who (sumber atau komunikator), Says What (pesan), in Which Channel (Saluran), to Whom (Penerima), with What Effect (Efek atau dampak). Lima elemen dasar dari komunikasi yang dikemukakan oleh Harold Laswell di atas akan bisa membantu para komunikator dalam menjalankan tugas mulianya. Berhasil tidaknya suatu komunikasi tergantung dari kelima elemen dasar tersebut. Bagaimana komunikator bisa mempengaruhi audiensnya, sehingga bisa bertindak sesuai dengan apa yang diharapkan oleh komunikator, bahkan bisa merubah sikap dan perilaku dari komunikan tersebut. Dalam pola komunikasi yang terjadi di desa Keseneng, masyarakat sebagi si "pemilik" air terjun sebagi kekayaan alamnya masih membutuhkan cara-cara strategis yang ditempuh untuk mengembangkan potensi alamnya. Pola komunikasi yang dilakukan selama ini adalah dengan melalui pamong budaya sebagai pemuka. Tugas pamong budaya adalah membimbing dan menjembatani komunikasi antara masyarakat lokal dengan pemerintah. Cara ini disebut Lazarsfeld menyebut two-step flow communication (aliran komunikasi dua tahap). Dan orang yang berpengaruh itu disebut opinion leader (pemuka pendapat atau pemimpin pendapat). Mereka berperan sebagai sumber referensi dari audiens untuk bertanya dan meminta petunjuk. Opinion leader bisa menjadi penginisiatif suatu pendapat sekaligus menjadi penjawab pertanyaan yang datang dari massa audiens.

Pada umumnya, hubungan antara opinion leaders dan massa audiens bersifat komunikasi lisan dan berjejaring. Pamong budaya selanjutnya 
menunjukkan strategi komunikasi yang harus dijalankan oleh masyarakat setempat, agar tercapai perubahan sosial. Menurut Schramm (1985) tugas komunikasi dalam perubahan sosial adalah: (1) Menyampaikan informasi kepada masyarakat pembangunan nasional, (2) memberikan kesempatan kepada individu-individu dalam masyarakat untuk mengambil bagian secara aktif dalam proses pengambilan keputusan, (3) tugas mendidik masyarakat, seperti diajarkan cara membaca, cara bertani dan sebagainya. Sebagai pemberi informasi dan sebagai pendidikdapat dilakukan oleh media massa, sedangkan dalam fungsinya sebagai penunjang dalam pengambilan keputusan diperlukan intensitas komunikasi interpersonal. Dalam kaitannya dengan pendekatan terhadap komunikasi pembangunan Dissayanake (Nasution,1988) menggambarkan bahwa pembangunan sebagai"...proses perubahan sosial bertujuan meningkatkan kualitas hidup dari seluruh atau mayoritas masyarakat tanpa merusak lingkungan alam dan kultural tempat mereka berada, dan berusaha melibatkan sebanyak mungkin anggota masyarakat dalam usaha ini dan menjadikan mereka penentu dari tujuan mereka sendiri". Pamong budaya sebagai "kepanjangan tangan "pemerintah sekaligus "penyambung lidah" masyarakat memegang kunci komunikasi untuk pengembangan obyek wisata. Secara struktural, posisi pamong budaya berada di bawah Dinas Pariwisata Kabupaten Semarang, dengan deskripsi tugas sebagai petugas yang mengayomi dan membina potensi lokal masyarakat, termasuk kebudayaan yang hidup di dalamnya beserta hasil cipta manusia di dalamnya.

\section{Kesimpulan}

Prinsip komunikasi adalah mengubah perilaku, strategi merupakan cara, metode, rencana atau pola yang dipergunakan dalam upaya menyampaikan pesan agar diikuti dengan perubahan perilakunya. Untuk mewujudkan hal ini, diperlukan pemrakarsa perencana, pengawas penyelenggaraan dan pembinaan. Opinion leader selanjutnya mengembangkan komunikasi jaringan dan merumuskan sebuah strategi untuk pengembangan desa. Metode yang dipilih adalah PRA/ Participatory Rural Appraisal. PRA yang dikembangkan oleh Robert Chambers lebih ditujukan untuk "orang luar", bagaimana seharusnya "orang luar", yang membantu masyarakat untuk mengembangkan dirinya, mendudukkan posisinya ditengah tengah masyarakat. "Orang luar" ini bisa para pegawai pemerintah, anggota LSM, para akademisi, dan sebagainya. PRA itu sendiri menurutnya adalah metode yang mendorong masyarakat pedesaan/pesisir untuk turut serta meningkatkan pengetahuan dan menganalisa kondisi mereka sendiri, wilayahnya sendiri yang berhubungan dengan hidup mereka sehari hari agar dapat membuat rencana dan tidakan yang harus dilakukan, dengan cara pendekatan berkumpul bersama.

Metode PRA dikembangkan berdasarkan atas prinsip dan teknik yang harus dikuasai oleh para fasilitator atau pemandu seperti halnya bagaimana pemandu melakukan model partisipatif dalam penjaringan informasi dan seterusnya. Pendek kata PRA bukan sesuatu harga mati, yang penerapanya banyak improvisasi sesuai dengan 
kondisi masyarakat yang ada. Penggunaan metode PRA sebagai salah satu strategi komunikasi ini membawa hasil yang cukup menggembirakan bagi perkembangan masyarakat desa. Intensitas komunikasi meningkat di setiap lapis masyarakat. Keterlibatan masyarakat untuk bekerjasama membuat komunikasi menjadi efektif, desa menjadi berdaya, aktifitas perekonomian menjadi hidup, dan secara langsung, segala aktifitas di dalamnya menjadi sebuah komunikasi pemasaran non formal bagi obyek wisata tersebut.

\section{Daftar pustaka}

Ahmadi, H. Abu. (1999). Psikologi Sosial. Penerbit Rineka Cipta: Jakarta.

Anonim. Tanpa Tahun. Pedoman Karang Taruna Dan Kegiatan Karang Taruna Jawa Tengah.

Bungin, Burhan. (2006). Sosiologi Komunikasi: Teori, Paradigma dan diskursus

Teknologi Komunikasi di Masyarakat. Prenada Media Group: Jakarta.

Depari, Eduard dan Colin MacAndrews. (1978). Peranan Komunikasi Massa Dalam

Pembangunan. Gadjah Madja University Press: Yogyakarta.

Effendy, Onong U. (1981). Komunikasi dan Modernisasi. Penerbit Alumni: Bandung.
Emery, Edwin. (1968). Introduction to Mass Communications. Second Edition: New York.

Eriyanto. (1999). Metodologi Polling Memberdayakan Suara Rakyat.Penerbit PT.

Rosdakarya: Bandung.

Gerungan, W.A. (1988). Psikologi Sosial. Penerbit P.T. Eresco: Bandung.

Hadi, Sutrisno. (1980). Metodologi Research Jilid 1. Yayasan Penerbitan Fakultas

Psikologi Sosial UGM: Yogyakarta.

Hunsaker, Philip L. dan Anthony J. Alessandra. (1986). Seni Komunikasi Bagi Para

Pemimpin, Penerbit Kanisius: Yogyakarta.

Korten, D.C. dan Sjahrir. (1988). Pembangunan Berdimensi Kerakyatan.Penerbit Yayasan Obor: Jakarta.

Liliweri, Alo. (1994). Komunikasi Verbal dan Nonverbal. Penerbit PT. Citra Aditya Bakti: Bandung. (1997). Komunikasi Antar Pribadi. Penerbit Citra Aditya Bakti: Bandung.

Littlejohn, S.W \& Karen A. Foss. (2005). Theories of Human Communication. Eight

Edition. Thomas Wadsworth: USA. 